\title{
FIDUCIARY RELATIONSHIPS IN OIL AND GAS JOINT VENTURES
}

\author{
D. A. MacWILLIAM*
}

\begin{abstract}
A party to a joint venture agreement in the oil and gas industry is often faced with the problem of determining whether or not he owes a fiduciary duty to his joint venturer. This article examines the many factual situations in oil and gas joint ventures which could give rise to a fiduciary duty and concludes that the extent to which the fiduciary principle is applicable to various relationships involving interests in oil and gas has not yet been determined by the courts. As such, the author suggests that in addition to attempting to provide in the agreement for those circumstances which could give rise to a fiduciary duty, a party to a joint venture who desires to avoid a breach of a fiduciary duty should make full disclosure to and attempt to get the consent of the other contracting party.
\end{abstract}

\section{A. INTRODUCTION}

Where in a joint venture in the petroleum industry one person undertakes to act in the interests of another a fiduciary duty may arise. It is not the intent of this paper to present a treatise on the nature of the fiduciary relationship, other than to provide a brief outline of the basic requirements for the existence of a fiduciary duty in particular situations. Rather, the purpose of this paper is to examine the many types of joint ventures in the petroleum industry to determine whether or not the same satisfy these requirements. It is hoped that this approach will assist a solicitor in recognizing potential fiduciary areas in activities proposed by his client and thereby better equip him in the drafting of the necessary agreements.

In the United States a joint venture has been distinguished from a traditional partnership in that a joint venture is usually formed to carry out a single transaction. However, the principles govering the rights and liabilities of the parties in both partnerships and joint ventures are very similar. According to Professor Howard R. Williams, the most important characteristic of a joint venture is that a fiduciary relationship of trust and confidence arises therefrom. He states as follows: ${ }^{1}$

Each party has the right to demand and expect from his associates full, fair, open and honest disclosure of everything affecting the relationship. One party may not exclude his associates from an interest in properties which are the subject matter of the joint venture by purchasing it for his undivided account, nor may he acquire an interest therein antagonistic to the interests of his associates. If he does acquire such antagonistic interest, he must account to the other participants in the joint venture therefor.

Let us consider certain types of activity in the operations of the petroleum industry involving joint consultation and action by two or more operators in order to determine whether the particular joint venture creates fiduciary duties, and if so, whether the duties were breached. As Cardozo J., stated in the case of Meinhard v. Salmon:"

Many forms of conduct permissible in the workaday world for those acting at arm's length, are forbidden to those bound by fiduciary ties. A trustee is

* Senior Solicitor, Mobil Oil Canada. Ltd.. Calgary, Alberta.

1 Williams, Fiduciary Principles in the Law of Oil and Gas, (1962) Thirteenth Annual Institute on Oil and Gas Law and Taxation, Southwestern Legal Foundation, 201 at 261 .

2 (1928) 164 N.E. 545 at 546 . 
held to something stricter than the morals of the market place. Not honesty alone, but the punctilio of an honour the most sensitive, is the standard of behaviour. As to this there has developed a tradition that is unbending and inveterate. Uncompromising rigidity has been the attitude of the courts of equity, when petitioned to undermine the rule of undivided loyalty by the disintegrating erosion of particular exceptions. Only thus has the level of conduct for fiduciaries been kept at a level higher than that trodden by the crowd. It will not consciously be lowered by any judgment of this court.

Professor Austin Scott has set forth one of the most quoted definitions of a fiduciary. In his view a fiduciary is: ${ }^{3}$

... a person who undertakes to act in the interests of another person. It is immaterial whether the undertaking is in the form of a contract. It is immaterial that the undertaking is gratuitous.

In his opinion some fiduciary relationships are more intense than others in that the greater the independent authority to be exercised by the fiduciary the greater the scope of his fiduciary duty. He summarized his paper by suggesting the following as typical cases involving breach of fiduciary duty:

1. Sale of trust property to the fiduciary. No matter how fair the price may be, the sale is voidable. It doesn't matter whether the fiduciary purchased the property directly or indirectly.

2. Purchase of property for the trust. The fiduciary violates his duty when he sells his own property to himself as fiduciary.

3. Other violations of the duty of loyalty:

(a) receipt of a bribe, commission or some other benefit for himself.

(b) purchase at a discount of an encumbrance upon the property.

(c) a person holding a lease in a fiduciary capacity obtaining a renewal of the lease for himself. The Meinhard v. Salmon case ${ }^{4}$ in which one joint adventurer was required to share with other participants in the venture the benefit of a new lease obtained prior to the expiration of a lease held by the joint venture.

(d) A fiduciary improperly competing with his principal, e.g. a fiduciary purchases property which he should purchase for his principal, if he purchases at all.

(e) corporate officers or directors seeking some advantage for themselves rather than for the corporation.

(f) a fiduciary who, acquiring confidential information in the course of his employment, uses such information for his own purpose or communicates it to a third person who may so use it. In a case of this kind a fiduciary duty may arise even though information is acquired by the fiduciary more or less accidentally and not in connection with the performance of his duties as a fiduciary.

The managing participant in a joint venture owes a fiduciary duty to the other participants and cannot acquire for his own benefit interests in property on the basis of information acquired in the performance of his duties. He will be held to be a constructive trustee for any interests so acquired. It is suggested that the courts use "joint venture" to provide a basis on which to find a fiduciary relationship. Once having so found, a breach of the fiduciary relationship will lead to the imposition of a constructive trust on the fiduciary. The Supreme Court of California commented in Anderson v. Stansbury as follows: ${ }^{5}$

The imposition of a constructive trust is an equitable remedy requiring the balancing of equities and where the venture is known to plaintiff and he does not claim his right to participate in a hazardous venture until the enterprise is successful, such delay will prohibit imposition of a constructive trust.

Whenever a person who is subject to fiduciary obligations acquires for himself a beneficial interest which may be said to be within the

3 Scott, The Fiduciary Principle, (1949) Proceedings of the Twenty-second Annual Meeting of the State Bar of California, 104.

+ (1928) 164 N.E. 545 .

i (1952) 242 P. 2d 305 
scope of the fiduciary obligation, the person to whom such duty is owed may seek to recover some share in such acquisition. Two questions must be answered in the affirmative in order to bring such a transaction within this obligation:

(1) Was there a fiduciary relationship between the parties, and, if so,

(2) Was the interest so acquired within the scope of the fiduciary duty?

Where the parties are participants in a joint venture the courts will endeavour to find a fiduciary relationship. The mere existence of such a relationship does not, however, require one party to share the benefits of his own enterprise with another. It is clear that the interest acquired must fall within the scope of the fiduciary duty.

If a person who undertakes to act in the interests of another person breaches his duty of undivided loyalty to that person by failing to disregard his own interests in exercising his fiduciary duty, he must account to the beneficiary for any benefit gained by him from such a breach. He must give to the beneficiary any profit resulting from his breach of duty. In Regal (Hastings) Ltd. v. Gulliver, Lord Russell of Killowen stated: ${ }^{\circ}$

The rule of equity which insists on those, who by the use of a fiduciary position make a profit, being liable to account for that profit, in no way depends upon fraud or absence of bona fides; or upon sucin questions or considerations as whether the profit would or should otherwise have gone to the plaintiff, or whether the profiteer was under a duty to obtain the source of the profit for the plaintiff . . or whether the plaintiff has, in fact, been damaged or benefitted by his action. The liability arises from the mere fact of a profit having in the stated circumstances, been made.

Mr. R. M. Davis states that the problem of conflict of interest is ${ }^{7}$

essentially as old as ethics and morals and older than the Bible mandate that 'no man can serve two masters'. It involves questions of honesty and fidelity and the old problems of deceit, disloyalty, bribery, corruption and subversion.

An examination of the case law leads one to the conclusion that there are many types of fiduciary relationships, each demanding a different code of conduct on the part of the fiduciary. This examination also indicates that oil industry activities serve to create fiduciary situtions to a greater degree than other major industries. The reasons for this are diverse and are a matter of opinion, but one can think of the following:

1. The research and discovery procedure involved in finding oil or gas. There are many people involved in this operation-geologists, geophysicists, landmen, lawyers, and drilling contractors and their personnel. Thus the oil company's vital secrets and plans are exposed to many people in different occupations and there is no secure protection of these secrets. Patent laws offer limited protection.

2. The tremendous and changeable values inherent in the oil industry. The individual, whether corporate president, independent geologist, lawyer or other, by reason of this value factor, is subject to considerable pressure and influence.

6 [1942) 1 All E.R. 379 at 386.

7 Davis, "Conflicts of Interest between Corporations and the Directors, Officers, Employees and Agents," (1962) Eighth Annual Rocky Mountain Mineral Law Institute, Vol. 8, at 191. 
With these unique attributes of the petroleum industry in mind, it is now necessary to examine the various types of joint ventures in the petroleum industry and apply to them the fiduciary tests already referred to.

\section{B. TYPES OF JOINT VENTURES}

Having considered the nature of the joint venture, the fiduciary duty and the constructive trust, this paper will now consider their application to various types of joint ventures in the petroleum industry.

\section{Grubstake Agreement}

A fiduciary relationship exists between the parties to a grubstake agreement (an agreement whereby one party pays the costs of another who will stake mineral claims for both parties), so that one party may not acquire benefits as a result of the operation without sharing such benefits with the other party. Normally, after the agreement is terminated neither party is obligated in the same way, but the grubstaked party must share with the financing party any interests acquired as the result of the discovery or location during the term of the agreement.

\section{Seismic Operations}

Situations are frequently encountered where two parties, $A$ and $B$, enter into an agreement whereby $B$, by conducting specified seismic operations on Blackacre and then providing the resulting information and data to $A$, shall have earned the option to drill a well on Blackacre by a specified date. If $B$ completes the well, he will earn an undivided fifty per cent interest in A's leasehold mineral interest in Blackacre.

Normally, a fiduciary relationship would not arise in the conduct of the seismic operation by $B$. If $B$ did not deliver the data and information to $A$, he would be in breach of the agreement. However, if the Crown was requesting bids for the adjacent Whiteacre property at a forthcoming Crown sale, and if B gave some of the seismic information with respect to Blackacre to a third party who was a potential bidder, along with $A$ and $B, B$ would be in breach of a fiduciary relationship to A. The same would hold true if, under the farmout agreement, the parties traded seismic information prior to the farmout well being drilled. In such a case, each would hold the traded material as a fiduciary to the other.

\section{Drilling and Geophysical Contracts}

Although in the strict sense, drilling contractors and geophysical companies are not involved in a joint venture with the company hiring them, reference is made to them in this paper, because of the number of situations where, in the conduct of its work, the contractor comes into possession of confidential information which is extremely valuable to the company, but only for so long as it is not revealed to outside parties. Therefore, care must be taken in the preparation of drilling and seismic contracts in order to provide for the maintaining of confidential information obtained by the drilling or geophysical company while conducting operations for the principal. However, even in the absence of such provisions, it is suggested that the contractor would 
have to account to the company for any profits it made as a result of the mishandling of such confidential information.

\section{Acquisition of Overriding Royalty}

Where the sole consideration for the assignment of a non-producing lease is a retained override, a fiduciary relationship may be created between the assignee and the assignor. If the assignee violates the trust and confidence placed in him by taking a top lease and permitting the assigned lease to terminate, equity will impose a constructive trust on the acquired lease in favour of the owner of the overriding royalty. This was the decision of Bolin v. Smith.

\section{Misuse of Confidential Information}

The acquisition of an interest in oil and gas as a result of unauthorized use of confidential information has often given rise to the employment of the constructive trust remedy. The mere existence of a principal-agent relationship does not mean per se, that an agent of an oil company engaged in the acquisition, development or exchange of oil and gas interests will hold any interest acquired on constructive trust for the principal. If the acquisition is not based on confidential information revealed to the agent by reason of his agency, he may acquire such interest for his own. But if the agent secretly uses for private gain confidential information obtained by virtue of his agency, he will hold any interests acquired on constructive trust for the principal, provided that the principal pays the cost of the acquisition. Others acting in concert with the agent are subject to the same rule. ${ }^{9}$

\section{Lease Broker}

Because of the number of published articles on the fiduciary responsibility of the lease broker and the independent geologist retained by a company, it is not the intention of the author to discuss further this facet of joint ventures. Suffice it to say that the cases, particularly in the United States, are clear that a lease broker or independent geologist, while acting as agent for a company, must not use confidential information supplied by the company in order to benefit himself, either directly by the acquisition of property in which the company might be interested, or indirectly, where he provided the confidential information to a third party for some ultimate benefit to himself.

\section{Co-tenancy of Mineral Interests}

If one co-tenant in an oil and gas lease purchases and then asserts a superior title in the leased interest to the detriment of his co-tenant, the courts have held that there is a fiduciary relationship and that the beneficiary is entitled to share in the benefits obtained by the other co-tenant, the fiduciary. Similar fiduciary relationships have been held to exist in the following situations, namely:

(1) where the co-tenant who is responsible to pay mortgage or lien payments on the leased interest fails to pay, and acquires the interest at a subsequent foreclosure sale. ${ }^{10}$

(2) where one concurrent owner, $A$, with special knowledge of the value of the leased interest fails to reveal the information to the other, $B$, before $B$ sells his interest to $C$, from whom $A$ later acquires the interest.11 


\section{Assignment of Mineral Interests}

Subsequent to a conveyance or assignment of an interest in an oil and gas lease, fiduciary principles may be applicable as between the assignor and the assignee by reason of the reservation of executive rights, or by reason of the retention of some reversionary interest by the assignor. In the absence of such rights or interests, fiduciary principles would not apply.

\section{Syndicate}

A promoter often seeks to obtain investments in a particular enterprise from persons with money who are attracted to such a deal as a means of reducing taxes through the depletion allowance and the option to expense intangible drilling costs. In exchange for investment money, the investor is given an undivided interest in a program for the acquisition, exploration and development of oil and gas interests. The promoter is the operator of the enterprise and the syndicate agreement gives him an undivided interest, often a carried interest, for putting the deal together. Often the agreement contains the following familiar words:

It is not the purpose or intent of the agreement to constitute a partnership, joint venture, association or other relationship.

While the main purpose of this language is to avoid liability by one participant for the torts or contracts of another, the language used may result in a negation of a fiduciary relationship." Therefore, the investor might want a provision in the agreement setting forth his rights to share in acquisitions of the operator.

\section{Consultants}

The leading case in the United States on the question of company geology and exploration departments is the case of Pratt v. Shell Petroleum Corp. ${ }^{13}$ wherein a Shell geologist, during the course of his employment, secretly acquired mineral and royalty interests in areas in which Shell was then interested. The Court held that it was not necessary for the plaintiff to show that it suffered detriment, injury or damage, and stated as follows: ${ }^{14}$

The law was indubitably contravened by the creation of a situation which leant inducement or temptation for wrong doing; and a court of equity does not concern itself with the question whether the opportunity was embraced and the principal suffered actual injury.

This case in effect recognized the integrated nature of the industry and refused to segregate its operations in determining the scope of the agency in conflict of interest cases. It confirms the proposition that an employer need not show injury or detriment by virtue of the employee's action in order to recover the gain and profits of the employee.

In Ohio Oil Company v. Sharp, ${ }^{1 ;}$ a third party acquired oil and gas leases based upon information received indirectly from an employee of Ohio. The employee did not acquire any interest in the leases, but

12 See Midcon Oil and Gas Limited v. New British Dominion Oil Company Limited [1958] S.C.R. 314, 21 W.W.R. 228 (C.A.), 19 W.W.R. 317 (Alta.), per Johnson, J.A., 21 W.W.R. at 234 .

13 (1939) 100 F. 2d 833.

14 Id. at 837 .

15 (1943) 135 F. 2d 303. 
the Court stated that the employee did surreptitiously and in violation of the trust relationship,

impart the valuable information to the defendant, who obtained it with knowledge that it was confidential; that it belonged to Ohio, and that it was disclosed to him in breach of the fiduciary relationship. In these circumstances, the defendant is an accessory to the unconscionable wrong, and he stands in the same footing as his benefactor. ${ }^{10}$

The Court held that the defendant was the constructive trustee of Ohio and as such acted for and on its behalf in the acquisition of the leases; it was therefore unnecessary for Ohio to show detriment, injury or damage, or to show that it would have secured the leases in question if the defendant had not wrongfully used the information obtained. This case should certainly stand as a clear warning to all persons within or without the oil and gas industry who acquire leases, minerals or royalties based upon information they receive from company employees.

A difficult situation arises where an employee has terminated his employment. The question then arises as to whether or not such an employee, having acquired special knowledge in respect to certain areas as a result of his employment, can use this information in dealings with third parties. The case of Morrison v. Woodbury, ${ }^{17}$ held that an employee who, after termination of his employment, used what was considered the property of the employer committed a breach of trust, which trust continues beyond the employment contract. In the case of Superior Oil Company v. Renfroe, ${ }^{1 *}$ the Court enjoined the defendant from further disseminating or using confidential maps or other information or data obtained while working for the plaintiff. However, the Court stated that the defendant was not to be enjoined from practising his profession as a geologist so long as he did not use the confidential information.

Another interesting case is Garst v. $S \operatorname{cott},{ }^{10}$ where the Court held that one who leaves the employ of another has the right to take with him all the skill he has acquired and all the information and knowledge he has received, provided that the confidential property of the employer is not misused. The Court further stated that trade secrets are the property of the employer and cannot be used by the former employee for his own benefit.

From these decisions it can be seen that the geologist who has worked as a corporate employee in a certain area and who has acquired a great deal of knowledge about certain data and production characteristics can certainly continue to use his knowledge. However, he cannot take with him seismographic information developed by the corporation, detailed subsurface studies or unpublicized well information. Similarly, a landman cannot, after employment with a corporation, use secret contracts of the corporation for his own benefit, and the same might apply to drilling obligations and other matters governing lease termination.

Turning now to consulting geologists retained by a company, it would appear from the cases previously considered, particularly the case

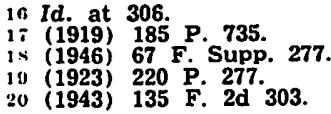


of Ohio Oil Company v. Sharp, ${ }^{20}$ that information acquired by a consulting geologist during the term of his employment is the information of the employer and is not to be used or divulged by the consultant. The same rule would apply to confidential information supplied to the consultant, that is, the confidential information supplied remains the property of the employer until such time as it becomes general knowledge by virtue of drilling or other exploratory geophysical activity.

To summarize the position of geologists and landmen hired by a company for a particular purpose, it can be concluded that the information obtained from their studies for the corporation is the property of the employer and cannot be used by the employee for his own benefit or for the benefit of third parties acting through him. On the other hand, these people cannot be limited in their future employment merely because they have made a study or have previously worked in the general area for another employer.

As to the lease broker's situation, in the case of Reese v. Harper, ${ }^{21}$ the Court stated that, because of the specialized service offered by the broker in acting as an agent for his client, there arises a fiduciary relationship between them, and the failure to discharge such duty precludes the broker's recovery for the service he purports to be rendering.

In the situation where two parties are arranging a joint bid for a parcel at a Crown sale, a fiduciary relationship could exist if confidential information of one company is given to the other for purposes of evaluating the parcel. The recipient of the confidential material would hold it as a fiduciary, and could not disclose it to a potential third party bidder, with whom the recipient wished to join in a bid for the same parcel. The fiduciary relationship would cease if the farmee decided not to drill the well and quit-claimed any interest in the agreement. At that point, it could deal safely with the information.

\section{Farmout Agreements}

Let us assume that our parties have passed with flying colours the fiduciary tests insofar as they pertain to seismic operations and Crown sale situations, and B then decides to exercise his option and drill the earning well on A's leased land, Blackacre. Under the terms of the socalled standard farmout agreement, $B$ would be required to provide certain information and samples to $A$ during the course of drilling, and normally the agreement would require $B$ to keep the same confidential. Absent such a provision in the agreement, a fiduciary duty would be imposed on B to prevent him from giving the information to another company.

\section{Joint Operating Agreements}

If $B$ has carried out his earning obligations, the normal result would be that Blackacre would become jointly owned by $A$ and $B$ in undivided interests and operated under the provisions of a joint operating agreement. Let us assume that $B$ is the operator, that the joint operating agreement does not contain a net profits interest provision (both parties are Canadian companies), that there is an area of common interest established around Blackacre, that the normal joint operating clauses with respect to non-consent operations, abandonment, surrender and

\footnotetext{
21 (1958) 329 P. 2d 410.
} 
duties of operator are contained therein, and that there is an express negation of a partnership or co-tenancy.

Fiduciary principles are applicable to the relationship of the operator under a pooling, unitization or joint operating agreement and are applicable to persons having interests in the property affected by such agreements. Authority for this proposition may be found in two cases, Young v. West Edmond Hunton Lime Unit,":- an Oklahoma case, and Midcon Oil and Gas Ltd. v. New British Dominion Oil Co., ${ }^{23}$ a Canadian case.

In the Young case, the plaintiff owned an interest in the production from the unit and the defendant was the Unit Operator. The plaintiff claimed that the defendant, as agent and trustee of the plaintiff, violated a duty owed to it in that the defendant failed to get the highest price available for the production. The Oklahoma Supreme Court characterized the obligation between the plaintiff and the defendant as follows: ${ }^{24}$

The unit organization with its operator stands in a position similar to that of a trustee for all who are interested in the oil production either as lessees or royalty owners.

The operator was authorized to purchase the oil produced, but the Court held that it must act with the highest fidelity when it purchases the oil. The Court described the relationship of the parties in fiduciary terms as follows: ${ }^{25}$

In equity, and under the statute permitting the creation of the unit, the unit, under the circumstances of its fiduciary relationship as revealed by the record, must account to the royalty owners, as to its handling of their affairs. It is charged with the knowledge of and the identity of its membership, including the royalty owners, for whom it was created, and, as a trustee, although acting in good faith, is accountable under the law.

Because of the numerous references to the Midcon case in articles dealing with the fiduciary problem, ${ }^{26}$ only a brief review of the facts is given herein. One party to an operating agreement, the plaintiff, sought to recover from the defendant operator, certain shares of stock acquired by the operator in a chemical company which purchased the gas produced by the operator for the joint account of the plaintiff and the defendant.

The majority decisions of Primrose $J$. at the Trial Division and of Johnson and McBride JJ.A. in the Appellate Division of the Supreme Court of Alberta and the dissenting judgments of Cartwright and Rand J.J. in the Supreme Court of Canada have been discussed by several writers. ${ }^{2-}$ It is suggested that the prevailing view in Canada is that the dissenting descisions of Rand and Cartwright JJ. will be accepted as law. The Judges who rendered the majority decision appeared satisfied to confine their search for a fiduciary duty to four corners of the operating agreement, a position which is not supportable on a proper interpretation of existing authority. It is suggested that in the future

22 (1954) 275 P. 2d 304, 3 O. \& G.R. 1736, 4 O. \& G.R. 68 (Okla.), appeal dismissed. (1955) 349 U.S. 909, 4 O. \& G.R. 1022, on later appeal, West Edmond Hunton Lime Unit $v$ Young (1958) 325 P. 2d 1047, 9 O. \& G.R. 534 (Okla.).

23 [1958] S.C.R. 314 .

$2+3$ O. \& G.R. at 1741 .

of 9 O. \& G.R. at 1741

27 9 O. \& G.R. at 540.

See Lewis and Thompson, Canadian Oil and Gas, Vol, 1. Div. A, Para. 149A; Bredin, Types of Relationships Arising in Oil and Gas Agreements, (1964) 3 Alta. Law Rev.
333; Ballem, The Scope of the Fiduciary Relationship, (1964) 3 Alta. Law Rev. 349; Muir, Duties Arising Outside of the Fiduciary Relationship, (1964) 3 Alta. Law 2 Id.

Rev. 359: Dunlop. Case Comment on the Midcon Case (1960) 1 Alta. Law Rev. 466. 
the courts will place greater importance on the following words of Rand J., namely: ${ }^{28}$

... the fiduciary remains as that of a trust in one who is to act in relation to the beneficial interest of another. It creates a standard of loyalty that calls for a refined sensibility to duty, the exclusion of all personal advantage and the total avoidance of any personal involvement in the interest being served or protected, a sense of obligation not always appreciated by those who enter upon it.

The minority judgments of Rand and Cartwright JJ. have been supported by the decision in Manning v. Calvan Consolidated Oil \& Gas Company Ltd. and Imperial Oil Limited (No. 2) ${ }^{21}$ which involved the consequence of a breach of fiduciary duty arising directly from the subject matter of a joint venture agreement. The facts in this case were that the plaintiff had acquired an undivided interest in a petroleum and natural gas permit owned by Calvan. Under the operating agreement Calvan, as operator, could dispose of the permit as it saw fit. Calvan entered into an agreement with Imperial which provided that Imperial acquired an undivided interest in the said permit and in two other permits owned by Calvan. The consideration was cash and required exploratory obligations. Manning was neither informed nor involved in these negotiations and refused to execute the resulting agreement when presented to him. Imperial at all times had knowledge of Manning's interest in the one permit and received an indemnification from Calvan. An unproductive well was drilled by Imperial on the permit in which Manning had an interest and exploratory drilling credits were thereby earned. The agreement between Calvan and Imperial provided that any credits which were surplus to the needs of the Manning permit could be distributed to the other two permits in which Manning had no interest. Even though Manning suffered no harm through this arrangement, the Court determined that a fiduciary relationship existed and that the consequences automatically flowed therefrom. The Court held that Calvan used joint property to secure a special advantage for itself. Because Imperial had notice of Manning's interest the Court held it equally responsible with Calvan for the breach of the fiduciary duty. Chief Justice McLaurin adopted the wording in Regal (Hastings) Ltd. v. Gulliver ${ }^{30}$ as follows: ${ }^{31}$

The general rule of equity is that no one who has duties of a fiduciary nature to perform, is allowed to enter into engagements in which he has or can have a personal interest conflicting with the interests of those he is bound to protect.

Although Calvan had the right to dispose of the permit as it saw fit, because the Court found that a fiduciary relationship existed, it did not hesitate to impose severe limitations and restrictions on this right.

\section{Independent Operations}

Perhaps the most obvious possibility for a fiduciary relationship is the conducting of non-consent or independent operations, but similar duties may also arise in the operator's handling of information resulting from joint operations, his disposing of production if not taken in kind, his carrying out of insurance requirements, his drilling of obligation wells, his disposal of an interest in the joint lands, and other

28 [1958] S.C.R. at 335 .

20 Reported in Lewis and Thompson, Canadian Oil and Gas, Vol. 1. Div. B., Dig. 183, 224.

30 [1942] 1 All E.R. 379. 
matters such as surrender, handling of bottom hole and dry hole contributions, first call on petroleum substances and the area of common interest.

Dealing first with non-consent or independent operations, the usual clause provides that if one party conducts independent operations he can recover from $100 \%$ of the production from the independent well his completion and operating costs (including royalty payments) plus a multiple of his drilling costs, such multiple increasing as the risk increases. Some agreements include completion costs with drilling costs in computing the penalty. If the independent operator conducts unnecessary logging or fracturing operations in connection with the well, installs unnecessary equipment such as casing, wellhead equipment, treaters, etc. or charges excessive labour costs to the operation so as to increase artificially the penalty to be received by him out of total production, it is suggested that there would be a breach of his fiduciary obligation. This can be prevented in the joint operating agreement by restricting the penalty application to drilling costs only, and also by providing that the penalty to be recovered shall not exceed the same multiple of the costs that would have been charged by an independent contractor for doing similar work at a competitive rate in the area.

Also in independent operations, if the party carrying out the operation has the right under the agreement to withhold well information and deny derrick-floor privileges to the other party while the drilling is undertaken and until the same is completed, and if there is a Crown sale in the area, there is a possibility that the party undertaking the independent operations might conduct his operations so as to keep the drilling rig on location or delay completion until after the sale. This possible breach of a fiduciary relationship can be covered by a provision in the joint operating agreement specifically denying the information until a specified number of days after the sale date.

\section{Area of Common Interest}

One area of joint operations giving rise to possible fiduciary duties is the clause frequently found in joint operating agreements dealing with an area of common interest. Usually the clause provides that if, during a specified period of time following the effective date of the agreement, either party acquires an interest in certain described lands encircling or adjacent to the then joint lands, the other party shall have the option to acquire an interest therein equal to its undivided interest in the joint lands. If the offer is accepted within the specified time and if the accepting party reimburses the first party for its share of the total acquisition costs, the land so acquired will become joint lands and subject to the joint operating agreement.

Very often Crown acreage which will be posted for sale will be close to joint lands. Generally the parties to the joint operating agreement will meet to establish a joint bid with both parties having the same geological information from the operations conducted on the joint lands. If one party is in possession of outside information not obtained under the joint account, which said information has a bearing on the value of the parcel for sale, has he an obligation to reveal it to the other? Surely he is only required to provide joint account information. 
Thus, if a joint bid cannot be agreed on, and the parties bid separately and the party with the outside information is the successful bidder, in the absence of fraud or misrepresentation, he should.be able to retain the entire interest.

On the other hand, the value to the holder of the outside information may be substantially increased because of joint information in the hands of both parties. Could not the person without such outside information successfully take the position that there can be no agreed bid price if one person is in possession of relevant information which the other does not have and which, although not obtained under the joint venture in the strict sense, was of greater importance because of joint venture information. If the party without the outside information was willing to pay his share of the costs of acquisition, why could he not obtain it as of right as the beneficiary under a fiduciary duty.

It is suggested that the joint operating agreement should contain a provision whereby any outside information not obtained for the joint account shall remain, for all purposes, the property of the party conducting the activity giving rise to such information. Most agreements take care of this potential problem by providing that if the successful bid varies by a specified percentage, for example $5 \%$, from the bid proposed by it at the negotiation stage, the other party may buy an undivided interest in the parcel.

\section{Use of Operator's Equipment}

In joint operating agreements the operator is required to carry on certain physical activities on the joint lands and to be reimbursed therefor in accordance with the accounting procedure annexed to the joint operating agreement. If the operator has its own subsidiary contractor and charges excessive rates to the joint account there would appear to be a breach of a fiduciary duty. Even if the contractor charged competitive rates the operator would be obligated to first advise the non-operator of his interest in the contractor or else he would have to reimburse the other party for the profits that he was making on the operations conducted by the subsidiary contractor. Agreements normally give the operator the right to carry out operations with his own personnel at competitive rates.

\section{Taking in Kind}

Joint operating agreements normally contain a provision whereby each party is entitled to take its share of production in kind at the wellhead and to separately dispose of the same. The clause usually provides that if a party does not so take in kind and separately dispose, the operator may purchase such production at the prevailing market price, or sell it to others, again at the market price. If the operator, in the absence of the market price qualification, buys such production at a distress price, he has breached his fiduciary obligation. In this regard, consideration should be given to the Midcon decision. ${ }^{32}$

\section{Suspension of Operations}

Current joint operating agreements give to the operator the right to suspend operations for the joint account if the non-operator fails to

$: 2[1958]$ S.C.R. 314. 
meet his financial obligations to the operator as set forth in the agreement. The question then is as to whether the operator, during the period of such suspension, is in a position to consider his obligations to the non-operator as also suspended until the obligations are met, either by cash or out of the non-operator's share of production. If he obtains information as operator during such period must he hold it in trust for the non-operator until such time as he is fully reimbursed?

\section{Surrender}

Consider the situation where $A$ acquires an oil and gas lease from $B$ and $B$ reserves a gross overriding royalty. In the absence of any restriction in the royalty agreement it is suggested that $A$ could surrender the lease without notice to $B$. If, however, there is a requirement in the agreement for $A$ to give $B$ notice of his intention to surrender 90 days prior to the termintion date of the lease so that $B$ may elect to take the lease, consider the situation where $B$, in response to the notice, first elects to acquire the lease, and then advises $A$ that $A$ should surrender it, all within the 90 day period. It is suggested that the safe thing for $A$ to do is to assign the lease to $B$. Otherwise he risks the possibility that if he surrenders the lease and then decides to reinstate it under the statute, it might be argued that $A$ has reinstated the lease as trustee under a constructive trust for $B$ alone.

On the other hand, if the operator under a joint operating agreement desires to surrender the leasehold interest in a portion of the joint lands, and if the leasehold interest is held by the operator in trust for both parties, then in the absence of a provision in the agreement, the operator could not surrender the interest without the prior consent of the other party.

\section{After Acquired Lands}

In general, it may be said that a fiduciary duty arises where one person entrusts property to another and relies on the other party to deal with the property for his benefit. The duty might also arise where one party entrusts property to another on the understanding that the undertakings on or with respect to the property will be taken by the beneficiary. If an operator is found to be in a fiduciary position to the non-operator then, based on the Midcon case, it is possible that the acquisition of after acquired lands is outside the scope of the fiduciary relationship in that the position of trust may have relevance only to the lands specifically covered by the agreement. The Midcon case would appear to say that there is not a comprehensive liability on the fiduciary inclusive of every activity in which it participates. Several cases in the United States are authority for the proposition that the fiduciary does not extend to the point where it would preclude one co-tenant from acquiring for his own benefit property not embraced in the enterprise and outside its scope, and that the extent and effect of the fiduciary relationship is determined by the written agreements between the parties. However, consideration should be given to Professor Scott when he states as follows: ${ }^{33}$

Where a person holds property in a fiduciary capacity, and it clearly appears that the acquisition of other connected property would be a particular advantage

33 Scott, supra, n. 3. 
to the estate which he holds as fiduciary, he cannot properly purchase this other property for himself.

If the joint operating agreement does not provide for the afteracquisition of adjacent lands, and if through information obtained for the joint account, adjacent lands appear desirable for purposes of acquisition, it is suggested that if one party acquires such lands, he acquires them as fiduciary for the other parties. Certainly the inclusion of a clause in the agreement describing after-acquired lands and specifying the manner in which they are to be acquired is essential.

\section{Title}

Another situation in the joint operating agreement where the fiduciary problem should be considered is the question of title. Presumably the farmee, before undertaking operations on the farmor's land for purposes of earning an interest therein, will be given certain information and documentation by the farmor for purposes of satisfying the farmee as to the farmor's title in the minerals. If the farmee discovers a lapse in the farmor's chain of title can he safely go out on his own and negotiate with the true owner of the minerals and thereby step into the shoes of the farmor, or, is he obligated to advise the farmor of his discovery?

\section{Gas Sales Contract}

In the Supreme Court of Canada decision in the Midcon case, ${ }^{24}$ Locke J. suggested that if New British had entered into a sales contract for the natural gas at less than a "fair value" without disclosure to Midcon there would have been a breach of "good faith" on the part of New British. He did not go so far as to say that there would have been a breach of a fiduciary duty. It should be noted that the price was a fair one, but it appears that the Court did not consider the fact that it was a twenty year contract and that what was a fair value at the time might be manifestly unfair a few years hence.

It would have been in the best interest of the promoter, as a producer of natural gas, to provide for a price escalation clause, but as a promoter of a fertilizer company, his position would dictate the opposite considerations. Surely this would have been a conflict of interest. It would have been a conflict of interest in the view of Rand J., because he stated as follows: ${ }^{3 i}$

... the operator, so developing, exploiting and marketing a jointly owned product for a joint benefit had reposed in him that reliance and confidence which constitutes a trust relationship.

Therefore, if under a joint agreement the operator has either the right or the duty to market both his share of the gas and the non-operator's share of the gas, he must be sure that the gas is sold for the then fair market price and adequate escalation provisions are contained in the contract.

\section{Unit and Unit Operating Agreements}

Many fiduciary problems which arise in unit and unit operating agreements have already been covered under the heading of "Joint

34 [1958] S.C.R. 314 .

35 Id at 329 . 
Operating Agreements"::i; However, there are certain situations which could arise with greater probability in unit operations than in the case of joint operating agreements.

One of these is the question of title. Where a title deficiency arises as a result of an investigation by the Titles Committee, can the working interest owners in the unit go out and acquire the tract for the unit and drain the production therefrom without advising the true owner who may not be a working interest owner? The suggestion is that they may do so without danger of breaching a fiduciary duty. However, if the unit operator on the instructions of the unit operating committee retains outside counsel to examine all titles and counsel advises the unit operator of a certain deficiency in title, it is very doubtful whether the unit operator could go out and top lease or otherwise acquire the interest in the questionable title and not offer the same to the working interest owner concerned, when the charges of the outside counsel are to the joint account.

On the other hand, does the Titles Committee have the obligation, if a material defect in a working interest owner's leasehold interest in a tract is discovered, to advise the working interest owner of the defect so that he may take the necessary remedial steps to perfect his title? He has revealed his records to the Titles Committee and the argument could be made that the Titles Committee, by accepting his records for examination, places itself in a fiduciary position with him. This matter should be clarified as between the working interest owner and the Titles Committee before the records are given over.

A situation which may arise in unit operations as well as under joint operating agreements is where the operator is drilling a unit well for the joint account of the working interest owners. In the course of drilling the unit well to the unitized zone, the operator penetrates a nonunitized shallow formation which is tested and found attractive. It is clear that the operator cannot retain this information for his own use and benefit. What is not quite so clear is whether his obligation is to give this information to all the other working interest owners or just to the working interest owner who has the lease covering the shallow formation. If the shallow rights are not leased, it is suggested that, because the operator came by his knowledge through joint account operations, he should provide all the working interest owners with the information so that a competitive leasing play could take place or, in the alternative, he could acquire the lease for the benefit of all the working interest owners.

\section{Pipeline Operations}

A possible conflict of interest situation in the ownership and operation of a pipeline could arise where $A$ owns and operates a pipeline and purchases crude oil from a field where $B$ and $C$ produce. In the purchase of the crude from $B$ and $C$ the question arises as to whether $A$ can charge a tariff which is profitable to him but decreases the wellhead profit on the gas to $B$ and $C$ who are not owners in the pipeline. If A's tariff is reasonable in the industry is he breaching a fiduciary? Obviously the answer would be in the negative. However, assume the case

31; Supra, p. 240. 
where $A$, the owner and operator of the pipeline, is also a joint producer with $B$ and $C$ in the field and operates for them. If $B$ and $C$ do not exercise their right to take in kind, what is A's position if he charges a high tariff for the transportation of the crude? It is suggested that $A$ as operator of the field would be breaching a fiduciary duty if he sells the crude under these circumstances. Conversely, if $A, B$ and $C$ own a pipeline with $A$ as operator drawing from a field in which $A$ and $B$ are producers, can A and B establish a low tariff so as to increase profits by way of depletion, and thereby adversely affect the profit picture of $\mathrm{C}$ who is owner only of an interest in the pipeline?

Another possibility is where A and B are producing gas in a field with $A$ as operator. $A$ and $B$ construct a gathering system to a pipeline which is owned and operated by $A$. A owns a refinery at the end of the pipeline. If $A$ charges too high a tariff is he accountable to $B$ in the absence of a common carrier designation?

\section{CONCLUSIONS}

The present status of the law in Canada on fiduciary relationships is anything but certain, but with the recent Midcon and Manning cases it is perhaps reasonably safe to make certain general observations. These are:

1. Where a confidential relationship exists between the parties, the courts are quick to find that such relationship is also a fiduciary relationship.

2. Fiduciary principles are usually applicable to most forms of joint endeavour, whether described as a partnership or, in less formal terms, as a joint venture.

3. Wherever the owner of an interest in oil and gas has power with respect to another person's interest therein, the courts will imply a fiduciary duty in connection with the exercise of such power. The person having the power is not permitted to base his conduct exclusively on his self-interest. He must give consideration to the effect of his conduct upon the interest of the other person.

4. In order to determine if a trust has been placed on a party who is to act in relation to the beneficial interest of another, a solicitor should examine not only the agreement between the parties, but also the fact situation in question and the circumstances in existence at the time.

5. Where in a joint venture circumstances arise where one party could hold a beneficial duty to another, it would not be sufficient to insert general wording in the agreement to the effect that a fiduciary relationship exists. It would be preferable in such situations to refer to "fair market value", "prudent operator", "reasonable costs" and similar phraseology.

6. Notwithstanding the statement of Primrose $\mathrm{J}$. in the Midcon case, it would not be prudent to rely on words such as

The operations of the parties shall not be considered as a joint venture and it is expressly agreed that it is not the purpose or intention of this agreement to create, nor shall the same be construed as creating any mining partnership, commercial partnership, or any partnership relation. 
as effectively eliminating the possibility of a fiduciary duty arising in the joint venture if the facts are otherwise.

7. A solicitor should always ensure that his client who is an operator of a joint venture

(a) makes full disclosure to the other of all proposed dealings with joint property,

(b) governs his conduct in the light of the interests of the other participants rather than exclusively in the light of his own economic interest, and

(c) shares his beneficial opportunities with the other participants.

From a practical point of view one might say that there are two obvious ways of avoiding a constructive trust situation resulting from a fiduciary relationship:

(1) By withdrawing completely from operations in the same general area as the joint activities.

(2) By failure to reap economic benefits from the enterprise in question. Few actions are brought for the privilege of participating in an unsuccessful venture.

However, the first alternative will not be attractive if the activity has a possibility of success and, as to the second, one would require a crystal ball in order to determine ahead of time the merits of a planned exploration programme.

By setting forth in the agreement those obligations of the parties which could give rise to fiduciary duties, the aggrieved party is restricted to suing in contract under the agreement rather than in equity for breach of a fiduciary duty. In addition to drafting a full and detailed agreement to cover the joint venture, it is better to err on the side of caution and to give full disclosure and get prior ratification from the other joint venturer before proceeding with the activity.

The ingenuity of petroleum companies to become involved in joint ventures and the touch of larceny in mankind, coupled with the relative high values on the acquisition and disposition of oil and gas rights, should make the area of fiduciary obligations a fertile field for oil and gas lawyers for some time to come. 